\title{
Cuerpos barrocos y vidas ejemplares: la teatralidad de la autobiografía
}

\author{
Jaime H. Borja \\ Pontificia Universidad Javeriana, Bogotá \\ borja@javeriana.edu.co
}

Fecha de recepción: 15 de septiembre de 2002

Fecha de aceptación: 1 de octubre de 2002

\begin{abstract}
Resumen
El cuerpo, presencia suprimida de la historia, encontró en el mundo barroco el primer gran espacio de autorepresentación. En el ambiente de la mística de la Reforma Católica se produjeron, durante el siglo XVII, textos autobiográficos escritos por monjas, en los cuales se encontraba reflejado el esfuerzo por proporcionarle un lugar al cuerpo como el gran teatro donde tenía efecto el ejercicio de la santidad, las virtudes, las visiones, los raptos. Estas vidas ejemplares siguieron el modelo retórico propuesto por Santa Teresa de Jesús, según el cual, la perfección del espíritu exigía una práctica corporal. De esta manera, el texto pretende acercarse a uno de los caminos de la retórica del barroco, aquella que construyó la mística del cuerpo en el mundo, es decir, la mística como experiencia sensorial y secular.
\end{abstract}

Palabras clave: HISTORIA DEL CUERPO, BARROCO, VIDAS EJEMPLARES, RETORICA, SIGLO XVII.

\begin{abstract}
The body, a suppressed presence in history, found in the Baroque world its first great locale for selfrepresentation. In the mystic ambience of the Catholic Reform in the $17^{\text {th }}$ century, autobiographical texts written by nuns reflected their efforts at providing a space for the body as the great theatre where sanctity, as well as the virtues, visions and raptures, was effected. These exemplary lives followed the rhetorical model proposed by Santa Teresa de Jesús in which spiritual perfection required bodily practice. In this manner, the text is an analytical approximation to one of the paths taken by Baroque rhetoric, that which constructed the mystique of the worldly body, that is, of the mystical as a secular and sensorial experience.
\end{abstract}

Key words: BODY HISTORY, BAROQUE, EXEMPLARY LIVES, RETHORIC, $17^{\text {TH }}$ CENTURY.

Fronteras de la Historia 7 (2002)

(c) ICANH 


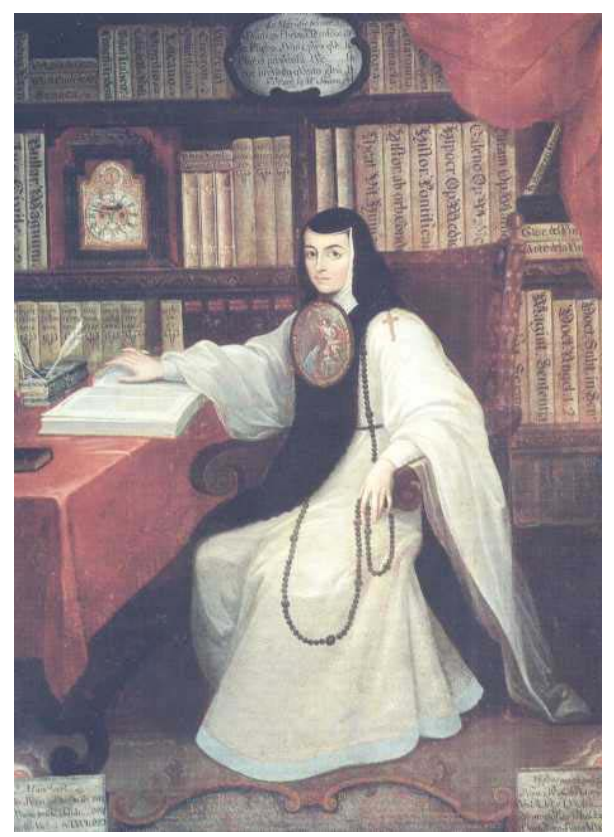

Este, que ves, engaño colorido, que del arte ostentando los primores, con falsos silogismos de colores es cauteloso engaño del sentido; este, en quien la lisonja ha pretendido excusar de los años los horrores, y venciendo del tiempo los rigores triunfar de la vejez y del olvido, es un vano artificio del cuidado,

es una flor al viento delicada, es un resguardo inútil para el hado:

es una necia diligencia errada, es un afán caduco, y bien mirado, es cadáver, es polvo, es sombra, es nada.

Sor Juana Inés de la Cruz

Miguel Cabrera. Sor Juana Inés de la Cruz. S. XVIII

\section{EI cuerpo y el barroco}

El cuerpo es la presencia suprimida de la historia. Su estudio, análisis y percepción cultural se ha supeditado a las prácticas y discursos generados por quienes habitan dichos cuerpos, sin que por sí mismo, sea un objeto de reflexión. Pero si se tiene en cuenta que el cuerpo es una experiencia que resulta de cada cultura y sociedad en la que se inscribe, su estudio posibilita la reconstrucción de las bases sobre las cuales se asientan los mecanismos de interrelación cultural y las ideologías que gobiernan los comportamientos intersubjetivos. Estas son las bases sobre las que reposan las representaciones que cada época hace del cuerpo, que de diferentes maneras, inciden en las prácticas culturales sobre las cuales se construyen las actitudes modernas.

Una acertada reflexión sobre el sentido histórico del cuerpo hace de Certeau cuando percibe la historia como constructora de cuerpos simulados que poseen dos valores, uno narrativo y otro representativo ${ }^{1}$, que son trasmitidos por los textos históricos. Entre todo el conjunto de actitudes

\footnotetext{
- Esta investigación contó con el apoyo del Instituto Colombiano para el Desarrollo de la Ciencia y la Tecnología Francisco José de Caldas (COLCIENCIAS) y el Instituto Colombiano de Antropología e Historia (ICANH).

${ }^{1}$ Michel de Certeau, "Historias de cuerpos", Historia y Grafia (México, D.F.), no. 9 (1997): 13.
} 
y comportamientos sociales, estos seleccionan determinadas series que se comportan como cartografías de esquemas corporales, los cuales conforman un sistema de convenciones que definen la sociedad narrada. En este sentido, el cuerpo se convierte en un discurso que autoriza y reglamenta las prácticas culturales, pero también está sujeto a selecciones y codificaciones de cada grupo cultural, lo que establece las maneras de pensarlo y percibirlo. Cada sociedad tiene su cuerpo sometido a una administración social: obedece a reglas, rituales de interrelación y a escenificaciones cotidianas.

Historiar el cuerpo es considerar cómo ha sido experimentado y expresado dentro de sistemas culturales concretos, lo que también involucra una historia de la necesidad de la identificación del sujeto con el otro, un grupo, un modelo común: este es el cuerpo social. Un nosotros que unifica un proyecto histórico matizado en la realización de los ritos sociales, en el hábito de la participación emocional que hace extensible el yo y en la articulación de lo público y lo privado. A partir de este hecho, se ordena el espacio social y el cuerpo se convierte en un vínculo cultural.

Uno de los momentos más importantes para el conocimiento de la historia del cuerpo, lo constituye el proceso de transformación social que siguió a la Reforma y su Contrareforma en el siglo XVI. La construcción de un nuevo cuerpo social, e incluso la misma representación del cuerpo individual, se hizo evidente en la medida en que se articuló un nuevo cuerpo místico eclesial, espacio que desarrolló plenamente el llamado período barroco ${ }^{2}$. A partir de entonces, el cuerpo místico se delimitó aún más por la doctrina, lo que impulsó nuevas representaciones de la corporeidad, una especie de tránsito antes que el cuerpo se convirtiera en la "colonia de la medicina o la mecánica" del siglo XIX.

Dentro de la experiencia del barroco indiano, las autobiografías se convirtieron en importantes espacios narrativos, especialmente el género que floreció en los conventos femeninos. Como textos históricos, las autobiografías expresan esas cartografías corporales que la conciencia barroca eligió como modelos de prácticas o vidas ejemplares; al mismo tiempo que se presentan como el discurso ideal para la conformación de un cuerpo social. Josepha de Castillo y Jerónima Nava, dos monjas clarisas neogranadinas del siglo XVII, son claros ejemplos de la manera como se podían elevar y teatralizar, barrocamente, las autobiografías como modelos espirituales, pero también corporales.

\section{Josepha de Castillo y Jerónima Nava}

Josepha y Jerónima tuvieron en común muchos espacios. Neogranadinas de nacimiento, fueron contemporáneas, llevaron vida de clausura en los conventos de clarisas en Santafé de Bogotá y Tunja, y ambas escribieron sus autobiografías por recomendación de sus confesores. Josepha de Castillo, sin proponérselo, se convirtió en una de las "autoras" más representativas del barroco neogranadino. Llevó una vida de clausura en la ciudad de Tunja entre 1689 y 1742, año

\footnotetext{
${ }^{2}$ Michel de Certeau, La fábula mística, siglos XVI y XVII (México, D.F.: Universidad Iberoamericana, 1993), 107.
} 
probable de su muerte, donde ocupó diversos cargos en su convento, y por encargo de su confesor empezó a escribir su autobiografía. A su muerte, sus dos escritos más importantes (Afectos espirituales y Su vida), cayeron en manos de sus parientes, quienes se dieron a la tarea de hacerlos públicos. De este modo, a comienzos del siglo XIX, su obra era conocida, ascendiendo al lugar de "escritora", lugar que los lectores de aquel momento le proporcionaron ${ }^{3}$.

De Jerónima Nava las noticias son escasas porque nunca se le reconoció como escritora, lo que no suscitó la curiosidad que propició la vida de Josepha. Antes de su muerte, acaecida en 1727, entregó a su confesor Juan de Olmos sus escritos autobiográficos, mismos que él reunió, ordenó y agregó un "Elogio de la autora", manuscrito que fue editado en $1994^{4}$.

Una pregunta que es necesario hacer en relación con el espacio en el que se circunscriben las autobiografías de Josepha y Jerónima, es el lugar desde donde se producen sus discursos, es decir, el carácter del barroco neogranadino. Tradicionalmente se ha sostenido la incorporación y pertenencia de la tradición cultural neogranadina a esa gran consecuencia postridentina que hoy se conoce como barroco. Pero ya desde hace más de 20 años algunos académicos, especialmente críticos de arte como Gil Tovar ${ }^{5}$, han cuestionado la existencia real de un barroco en estos territorios andinos. La inquietud se puede trasladar a espacios más complejos, el entorno cultural del siglo XVII, en el cual la pregunta es si se llevó a cabo una experiencia barroca como una forma de concebir la cristiandad. Esto es, una teatralidad que se refleja en la espiritualidad, en los gestos, en las representaciones de la vida, la muerte, la fiesta, el cuerpo y hasta en una experiencia gastronómica ${ }^{6}$.

Este debate, que no es parte del presente artículo, es un asunto de largo alcance. Sin embargo, para su discusión se deben considerar aspectos como la ausencia de una corte virreinal en el Nuevo Reino durante el siglo XVII, la pobreza económica de la región, las dificultades de comunicación que impidieron el acceso de estilos, modos y modas artísticas e intelectuales, la carencia de una conciencia de continuidad cultural, la falta de procesos de evangelización compleja, etc. Pese a estos planteamientos, existe la certeza que si bien las prácticas no fueron en pleno sentido barrocas, si lo fue el discurso; Josepha de Castillo y Jerónima Nava son dos casos. Esta percepción se desprende de la circulación de textos barrocos en el medio colonial neogranadino, desde el ámbito discursivo y textual, como fueron los sermonarios, manuales de pintura, escritos retóricos, teatro, literatura etc. Estos crearon textualmente una influencia barroca evidente, pero no más allá del status estético al que normalmente se ve sometido.

\footnotetext{
${ }^{3}$ Francisca Josefa del Castillo y Guevara, Afectos espirituales, 2 vols., Biblioteca de Autores Colombianos, nos. 104105 (Bogotá: ABC, 1956), y Su vida: Escrita por ella misma por mandato de sus confesores, Biblioteca de Autores Colombianos, no. 103 (Bogotá: Ministerio de Educación Nacional, 1956).

4 Ángela Inés Robledo, ed., Jerónima Nava y Saavedra, 1669-1727: Autobiografía de una monja venerable, Colección Literatura (Cali: Centro Editorial Universidad del Valle, 1994).

${ }^{5}$ Francisco Gil Tovar, "Del aparente barroco en Colombia", Revista del Colegio Mayor de Nuestra Señora del Rosario (Bogotá), no. 512 (1980).

${ }^{6}$ Esta problemática es la que Bolívar Echeverría ha llamado ethos barroco. Echeverría, La modernidad de lo barroco (México, D.F.: Era, 1998).
} 
Este contexto discursivo barroco hace posible comparar las autobiografías de las dos monjas clarisas, aunque en su concepción sean diferentes. La conocida obra de Josepha se abre en dos fuentes: $S u$ vida es una narración testimonial desde el cuerpo, relata cronológicamente el proceso vocacional, la familia y la vida conventual, expresando sentimientos y encuentros diarios; mientras que Afectos espirituales es un testimonio del alma, como intuitivamente lo entendiera Darío Achury Valenzuela, prologuista a la edición de $1956^{7}$. Por su lado, la autobiografía de Jerónima Nava, funde lo corporal y lo espiritual en un solo relato, con menos señales particulares y enfatizando la experiencia mística desde las visiones.

Sin embargo, estos dos textos no se pueden tomar como un testimonio verídico de lo que era ser monja de clausura entre finales del siglo XVII y la primera mitad del XVIII; o lo que era la vida conventual o las condiciones de mentalidad para la misma época. Obras de esta naturaleza, encomendadas por el confesor, se constatan a lo largo y ancho de América hispánica, y casi todas ellas conservan la misma estructura. Es el caso de la vida de la quiteña Mariana Flores Paredes, conocida como Santa Mariana de Jesús, Santa Rosa de Lima, o las mexicanas Mariana e Inés de la Cruz, todas ellas en el siglo XVII. Las primeras se conocen por sus escritos, las dos últimas por las narraciones que dejó Carlos Sigüenza y Góngora en el Paraíso occidental.

\section{La obra, la estructura}

La retórica, más allá de comportarse como un arte, fue una técnica que se empleó para la persuasión, y como tal se aplicó a todas las instancias del conocimiento. El uso de la retórica se remonta a la antigüedad, pero durante la Edad Media se incentivó su utilización y más aun a partir del siglo XVI, cuando en el contexto de la Reforma, se estableció una preceptiva católica aun más compleja con el fin de cumplir con las nuevas necesidades persuasivas que surgían de la evangelización. De este modo, con el desarrollo del Barroco, la retórica sirvió para la exaltación de los sentidos, por lo que no sólo se empleó en la palabra escrita y oral, sino que su uso se extendió al tratamiento de las imágenes. De cualquier modo, la retórica servía para persuadir siguiendo tres objetivos: enseñar, deleitar y mover los sentimientos, en otras palabras, se trataba de persuadir a una causa, mostrando vicios y virtudes.

Desde este contexto, los escritos autobiográficos de Josepha de la Concepción y Jerónima del Espíritu Santo, sus nombres de profesas, conservan un claro sentido retórico con el cual pretendían persuadir al lector hacia los sabores y las ventajas de la vida penitente, la vida ejemplar del buen cristiano ${ }^{8}$. En este sentido, no se trata solamente de obras que están dentro del ambiente de la mística barroca; o autobiografías que reflejan aquel complicado proceso del tránsito a la modernidad (como autoconciencia de sujeto); tampoco son "fuentes objetivas" que

\footnotetext{
${ }^{7}$ Darío Achury Valenzuela, “Estudio preliminar”, en Su vida, por Castillo y Guevara, 39-44.

${ }^{8}$ Las autobiografías de monjas coloniales como problema literario e histórico ha sido ampliamente estudiado. Como introducción se pueden ver: Kristine Ibsen, Women's Spiritual Autobiography in Colonial Spanish America (Gainsville: University of Florida Press, 1999); Electa Arenal y Stancey Schlau, Untold Sisters: Hispanic Nuns in Their Own Works (Albuquerque: University of New Mexico Press, 1989); y Alison Weber, Teresa de Avila and the Rhetoric of Feminity (Princeton: Princeton University Press, 1996).
} 
sirven para reconstruir el mundo conventual del siglo XVII. Son textos autobiográficos elaborados con una intención persuasiva, en los que sus autoras narran humildemente los inconmensurables esfuerzos para alcanzar la santidad, objetivo fundamental de cualquier monja al ingresar al convento, a lo cual dirigen sus mejores esfuerzos. La santidad es una obligación del cristiano y uno de los temas barrocos por excelencia ${ }^{9}$.

El discurso hagiográfico hace de la autobiografía del virtuoso, un material con el que se construye la imagen de un cristiano ejemplar, una imagen digna de imitarse. En el discurso de $S u$ vida, Josepha lleva a cabo una retrospectiva de su existencia abarcando aquellos momentos esenciales: infancia, adolescencia, entrada al convento, profesión y la atribulada vida conventual, para ella, más llena de desdichas que de alegrías. Jerónima, por su parte, empieza su diario ya profesa, después de una azarosa experiencia de enfermedad. Ambas monjas esbozan un cuadro de las pasiones y las virtudes humanas, recogen sus experiencias tanto terrenas como místicas -visiones, raptos, sueños sagrados- en función de demostrar sus procesos personales de santidad. Como todo discurso de vidas ejemplares, son desmedidos, no temen alejarse de la realidad empírica de los hechos.

La cultura barroca, hija de la reforma de Trento, había impuesto métodos para alcanzar la santidad, entre las cuales se contaban las técnicas ascéticas. Los cuatro personajes que comparativamente se han mencionado, santa Mariana de Jesús, santa Rosa de Lima y las mexicanas Mariana e Inés de la Cruz, traslucen en sus escritos las mismas fuentes, consideradas adalides de la Reforma, El libro de su vida y El camino de la perfección de Santa Teresa de Jesús y Ejercicios espirituales de San Ignacio de Loyola. Estas lecturas obligadas, fueron empleadas como modelos de vida, pero también de escritura. Ignacio proporcionaba la estructura de comprensión narrativa y la capacidad para organizar las descripciones retóricas con base en un elemento de su espiritualidad, "la composición de lugar", que definía como: "la composición será ver con la vista de la imaginación el lugar corpóreo donde se halla la cosa que quiero contemplar". Por su parte, santa Teresa proporcionaba el modelo para narrar una autobiografía, aspecto mencionado por Darío Achury Valenzuela, quien percibió la similitud de los hechos de vida en la obra de Josepha ${ }^{10}$, pero no de qué manera se tomaba de ésta el modelo narrativo.

Con base en estas fuentes, estos relatos autobiográficos relataban realidades textuales, no necesariamente realidades vividas, que por si mismas eran verosímiles en el sentido que eran creíbles de verdad. Esta es la razón por la cual la vida de monjas, a partir de sus retóricas autobiografías, eran muy similares. Pero más allá de las semejanzas, sus escritos remiten a una representación del cuerpo. El modelo de vida narrado por Josepha de la Concepción, al igual que Teresa, Rosa, Inés o Mariana, es escogido siendo muy niña; un modelo de santidad, que entre todo el acervo de modelos posibles, es el mismo: santidad eremita, santidad mártir. Jerónima, aunque no menciona su infancia, alude al mismo modelo. Este elemento revela ya una idea clara del cuerpo barroco: el cuerpo sufriente y aislado, es la experiencia mística necesaria

\footnotetext{
${ }^{9}$ Antonio Rubial García, La santidad controvertida (México, D.F.: Fondo de Cultura Económica, 1999), 38-42.

${ }^{10}$ Darío Achury Valenzuela, "Estudio preliminar", en Su vida, por Castillo y Guevara, 31-35.
} 
para que la corporeidad no sólo sea un obstáculo y enemigo a vencer, sino también un espacio teatral que permite su disfrute pero poseído místicamente por el alma.

El discurso de las dos clarisas compartía con sus contemporáneas un mismo repertorio de imágenes, la misma concepción retórica y formas similares de teatralidad. Las fuentes mencionadas proporcionaron una amplia preceptiva que no sólo afectaba la idea de modelo de vida, sino también proveía un patrón de comportamiento corporal que servía para acercarse al modelo de santidad elegido.

\section{El modelo}

Para la espiritualidad barroca el cuerpo estaba concebido como un espacio teatral, y como tal, tenía un aparato escénico y un lugar de representación. Además de estas características, se debe tener en cuenta que el barroco es el tránsito entre lo oral y lo escrito, lo público y lo privado, sombra de modernidad. Por esta razón, la teatralidad se mantenía reservada a lo privado, para transitar lentamente a lo público. Estos elementos están caracterizados en la obra de Josepha desde los primeros párrafos de su narración, en los cuales elige y escenifica los lugares donde transcurre su experiencia corporal, esto es el tránsito de la casa de sus padres al convento, espacios siempre representados por lo oscuro y lo sombrío. Desde su infancia, el cuerpo se ubicaba en los lugares más apartados, preámbulo a la vida de clausura, lo que demarcaba y preanunciaba su elección de la vida ermitaña.

Su experiencia infantil, como sucede en la mayor parte de los escritos autobiográficos, marcaba un punto de relación con su cuerpo enfermizo, lacerado y débil, a partir del cual su vida se convertía en un acto de intimidad, al que ni siquiera tenían acceso sus padres. Con el paso del tiempo, estos actos traspasaban el umbral a lo público en la medida en que llamaba la atención sobre su conducta como un modelo social para seguir.

Este modelo social estaba inspirado en la imagen del cuerpo sufriente que actuaba a la manera de una "cárcel de purificación", elemento determinante de la relación con el cuerpo en las narraciones de Jerónima y Josepha. Entre todo el arsenal de imágenes que ofrecía la cristiandad, el arquetipo religioso que cohesionó esta imagen de cuerpo en la experiencia barroca neogranadina fue el Cristo sufriente, representado en sus múltiples situaciones: el Cristo de la columna, el flagelado, el caído, el crucificado, el calvario, el de la paciencia, etc. Las posibilidades de escoger modelos eran infinitas, desde el niño Jesús, tan representado en la iconografía; o el Cristo resucitado; el milagroso o el salvador, pero el que causaba un gran impacto en sus visiones o en sus textos, era esta figura prototípica que representaba a Cristo con el cuerpo lacerado, imagen digna de imitarse ${ }^{11}$. Jerónima, en sus visiones, se dejaba atraer incansablemente por las llagas, el costado abierto, el Cristo de la columna, el crucificado, el azotado, a partir de lo cual elaboraba los relatos de esta manera:

\footnotetext{
${ }^{11}$ Véanse las visiones del Cristo flagelado, la corona de espinas y el Cristo crucificado, en Castillo y Guevara, $S u$ vida, 162, 153, 177.
} 
Estando un día saludando las llagas de mi Señor y regalándome con aquel mar dulcísimo de la sangre de su costado, me parece que llegó a mí tanto su sagrada cabeza que casi sensiblemente la sentí $[\ldots]^{12}$.

Los medios para asimilar esta representación arquetípica y volverla cuerpo, fueron varios: desde la gran cantidad de narraciones contenidas en sus escritos acerca de sus vidas enfermizas y siempre a punto de morir; hasta la identificación con santos de su devoción, modelos ejemplares que inspiraban sus actos. Josepha acoge a Santa Magdalena de Pazzi (1566), una de las santas extáticas más populares del Carmelo, modelo de santidad que dormía con corona de espinas y tenía el don de los milagros; caracterizada por el voto de castidad que hizo en secreto y que defendió hasta el final frente a la obstinación paterna. Como Josepha, sufría de ataques corporales constantes, cuyas dolencias la postraban. Jerónima se inspiraba en Santa Gertrudis (1302), famosa por sus escritos y ejercicios ascéticos.

\section{La santidad}

De acuerdo al modelo propuesto por santa Teresa de Jesús, y seguido por sus contemporáneas, el llamado a la santidad se sentía en la infancia. Este modelo tendía a reforzar la representación del cuerpo como un ente llamado a su espiritualización desde los primeros momentos de la vida. Pero para que esto fuera efectivo había que tener cierta disposición a aceptar y escudriñar los símbolos que Dios colocaba en el camino, de lo que especialmente Josepha es consciente como lo refleja en los primeros capítulos cuando narraba su temprano discernimiento del pecado. De su infancia, se dolía por haberse dejado tentar por los libros de comedia, cuya lectura le valía un castigo de Dios ${ }^{13}$. A partir de estos primeros indicios, se conformaba un método para alcanzar la santidad, lo cual permitía organizar las prácticas que definirían el camino de la perfección, y de nuevo, todo comenzaba con el trabajo del cuerpo:

Tuve siempre una grande y como natural inclinación al retiro y la soledad; tanto, que, desde que me puedo acordar, siempre huía la conversación y la compañía ${ }^{14}$.

La cristiandad ofrecía múltiples posibilidades de modelos de santidad, pero como ya se ha mencionado, las dos clarisas eligieron la muy barroca vida ascética. No es gratuito que dentro de la estructura retórica de la obra, Josepha tomara como fecha de su nacimiento el día de San Bruno $^{15}$, conocido místico medieval fundador de la Cartuja, ejemplo de la vida solitaria, con lo que quería recalcar que su vocación estaba marcada por Dios desde su mismo nacimiento. Por su parte, Jerónima tomaba a Santa Gertrudis, la austeridad y del desprecio por el mundo. Una característica común en ambos modelos, era el voto de silencio, fundamentador de la espiritualidad, aspectos que tanto Jerónima como Josepha ratificaban como suyos cuando afirmaban cuanto les valía el retiro, la abstracción y el silencio.

\footnotetext{
${ }^{12}$ Robledo, Jerónima Nava y Saavedra, 155.

${ }_{13}^{13}$ Castillo y Guevara, Su vida, 64.

${ }^{14}$ Ibídem, 60.

${ }^{15}$ Ibídem, 59.
} 
De esta manera, la vida eremita no significaba separarse del mundo sino enfrentarse a su propio cuerpo. La elección de la vida de clausura era, para su época, la mejor manera de experimentar el eremitismo, lo que a su vez posibilitaba que el cuerpo se diera en solitario, pero formando parte de un cuerpo místico eclesial que estaba representado en la experiencia comunitaria. Los relatos de Josepha y Jerónima abundaban en narraciones que contaban las discordias conventuales, y ellas, se presentan como las víctimas de los enfrentamientos. En el retiro casi desértico, la vida era una tragedia y el cuerpo habita esa tragedia que se manifestaba en las múltiples posibilidades de inadaptación al entorno social y conventual.

A medida que avanzaban sus experiencias de vida, las indicaciones de perfeccionamiento por parte de Dios se agudizaban, lo que narrativamente significaba la aspiración a espiritualizar el cuerpo. Ambas enfatizaban en una conducta sistemática ejercida desde la infancia, cuyo objetivo era lograr la perfección y crear un catálogo de virtudes propiciadas por el esfuerzo constante y reiterado. Ese catálogo de virtudes perfeccionaba el espíritu, pero su consecución exigía una práctica corporal. Josepha, a los 14 años se propone "imitar a los santos", para lo cual deja las galas, se viste de sayal y, con toda naturalidad, hace "muchas disciplinas con varios instrumentos, hasta derramar mucha sangre. Andaba cargada de cilicios y cadenas de hierro, hasta que sobre algunas crecía la carne"16.

En este sentido se puede hablar de una retórica corporal que acompañaba la oración. Retórica asociada a un ejercicio físico, reglamentado por la escritura, es decir, una persuasión en donde se delineaban posturas claves, un espacio de gestualidad que por sí mismo expresaba un proceso de espiritualización corporal propiciatorio. Ponerse en pie, de rodillas, postrarse en el suelo, arrinconarse, alzar los ojos al cielo, abrir los brazos en cruz, caminar con los pies y los brazos atados, pasear; eran preceptos que cada practicante de esta retórica corporal adecuaba a sus propias necesidades. Este era el sentido de llevar a cabo un "ejercicio" espiritual, en el sentido ambiguo de la palabra, que aspiraba al diálogo y a una composición de lugar ${ }^{17}$.

De esta manera, la comunicación con Dios se lograba sólo mediante una práctica ascética, cuyo escenario era el cuerpo. Este era un camino barroco, la búsqueda de la santidad a través del cuerpo, como cultivo de la mística en una modalidad novedosa: la mística del cuerpo en el mundo, es decir, la mística como experiencia sensorial y secular. Un rasgo de modernidad se delineaba entonces en sus textos: la exagerada conciencia del cuerpo.

\section{Dominar y domar el cuerpo}

La comunicación con Dios y la aspiración de la santidad, implicaba una preparación espiritual, cuyo primer paso era necesariamente la dominación del cuerpo. Al "domesticarlo", no se trata solamente de castigarlo para rechazar su condición material, por el temor, o para crear una

\footnotetext{
${ }^{16}$ Ibídem, 73.

${ }^{17}$ Margo Glantz, "El cuerpo monacal”, en Barrocos y modernos: Nuevos caminos en la investigación del barroco iberoamericano, ed. Petra Schumm (Frankfurt: Vervuert Verlag; Madrid: Iberoamericana, 1998), 195.
} 
ruptura con el pecado que podía representar el cuerpo. Estas formas de castigo, más que rechazo, implicaban una manera de perfeccionar lo imperfecto, de domesticar lo que por naturaleza era pasional y salvaje ${ }^{18}$. Los manuales de la época y las fuentes de las que se ha hablado que influyeron en las dos autoras, como Ignacio de Loyola y Teresa de Jesús, aconsejaban la metodología de domesticar el cuerpo, lo que además recordaba que su función para los ascetas de la Tebaida era probar la fortaleza por medio de la tentación: finalmente el "retiro" en el desierto o en la clausura, era el imaginario fortalecido, el ideal de un cuerpo barroco.

El cuerpo era el teatro de vida, como habitáculo del alma, debía ser perfeccionado. Josepha y Jerónima narraban diversos mecanismos y formas proporcionados por Dios mediante los cuales se le podía domar. A un conjunto de estos mecanismos se pueden catalogar como indirectos, en la medida en que eran beneficios adquiridos por gracia de Dios, como la enfermedad, un lugar común en sus argumentaciones. En todas las etapas de sus vidas, especialmente aquellas de oscuridad espiritual, sus cuerpos permanecían enfermos como reflejo de las debilidades del alma. Cuenta Jerónima que

Luego que se conoció el gran peligro del achaque, habiendo desahuciado todos los médicos y recibido, sin merecerlo, los santos sacramentos, oí una voz en mi interior que me decía: "no morirás por ahora, durará tu padecer por diez años, aunque no en todos será igual el tormento". Entendí que el Santo Apóstol me negoseó este padecer, conmutándome en él las terribles penas que me esperaban por mis gravísimas culpas ${ }^{19}$.

Un cuerpo que buscaba santidad era un cuerpo lacerado que sólo sanaba en la medida en que había tranquilidad y encuentro con Dios, pero como la búsqueda era constante, el alma siempre permanecía atribulada. Esta situación se explica por la todavía empleada tradición medieval que justificaba que el cuerpo era fiel reflejo del alma, su epifanía.

Uno de los tópicos retóricos atractivos en sus obras, era el empleo de la enfermedad como alegoría. Josepha sentía en su cuerpo, en su búsqueda espiritual, los dolores de Cristo. Discretamente y evitando la comparación con su padre de Orden, San Francisco, quien recibió los estigmas, narraba cómo su cuerpo enfermó con intensos dolores en las manos, los pies y el corazón, los lugares de las llagas:

Yo padecía gran trabajo en lo corporal, y espiritual; en lo espiritual, porque me dio nuestro Señor un modo de padecer que parecía me ahogaba interiormente, y aquel modo de pena era sensible, de modo que resultaba al cuerpo, principalmente los pies, las manos y el corazón me dolían y atormentaban con un desasosiego y apretura, que pasaba muy amargamente ${ }^{20}$.

\footnotetext{
${ }^{18}$ Michael Foucault, Historia de la sexualidad (México, D.F.: Fondo de Cultura Económica, 1991), 2.

${ }^{19}$ Robledo, Jerónima Nava y Saavedra, 61.

${ }^{20}$ Castillo y Guevara, Su vida, 126.
} 
La vida enferma desde la infancia, era un recurso para demostrar como ésta era un regalo de Dios, enfermedad siempre ligada a un espacio de sacralización. Jerónima, en sus visiones previas o posteriores a la enfermedad, desarrollaba de manera similar un culto a las heridas, lo que evidenciaba cuando narraba que en sus estados extáticos Cristo se le aparecía

[...] mostrándome aquella franca y amorosa puerta de su costado me ha metido en su pecho, regalando y acariciando a esta serpiente como si fuera paloma; dándome a beber la sangre de su mismo corazón $[\ldots]^{21}$.

Además, existían otros mecanismos para purificar el cuerpo: dormir en el piso, buscar la incomodidad, comer, como los padres del desierto, con alimentos descompuestos, o en el mejor de los casos, flores. En igual dimensión, rechazaban todo lo que podía representar el vano paso por este mundo, como el vestido y lo que adornaba el cuerpo, todo ello objeto de vituperio. Sin embargo, había formas más directas de autocastigarse. Como las otras monjas ya mencionadas, modelos de santidad de su época, los cilicios, las cuerdas y las ortigas, permitían la domesticación del cuerpo infligiéndole el dolor sensible. Ignacio de Loyola lo recomendaba:

[...] castigar la carne, es a saber, dándole dolor sensible, el cual se da trayendo cilicios o sogas o barras de hierro sobre las carnes, flagelándose o llagándose de otras maneras de asperezas ${ }^{22}$.

Decía, a propósito, Josepha de la Concepción:

¿Pues, cómo diré, Dios mío, los males y profundidades en que me vi, con tentaciones horrorosas en ésto, ni las cosas que movía el enemigo en lo exterior e interior, ni la guerra que yo tenía en mí misma?

Poco o nada pueden las fuerzas humanas contra este maldito vicio, tan llegado a nosotros mismos, que esta carne vilísima, saco de podredumbre, si Dios se aparta. El altísimo don de castidad y pureza que hace a las almas esposas del altísimo Dios, desciende de arriba, del Padre de las Lumbres. Despedazaba mi carne con cadenas de hierro: hacíame azotar por manos de una criada; pasaba las noches llorando; tenía por alivio las ortigas y cilicios; hería mi rostro con bofetadas; y luego me parecía que quedaba vencida a manos de mis enemigos. Andaba llena de pavor y horror de mí misma, sin atreverme a alzar los ojos a Dios, ni a su Santísima Madre, y en ella me faltaba el consuelo y la vida. Consultaba continuamente a mi confesor, y ponía esfuerzo en tomar los medios que me daba; mas yo conocía que el altísimo y limpísimo Dios quería así humillar mi soberbia, y que me aborreciera a mí misma, como a un costal de estiércol ${ }^{23}$.

\footnotetext{
${ }^{21}$ Robledo, Jerónima Nava y Saavedra, 75.

${ }^{22}$ Ignacio de Loyola, Obras (Madrid: Biblioteca de Autores Cristianos, 1991), 244.

${ }^{23}$ Castillo y Guevara, Su vida, 144.
} 
Con el autocastigo se imitaba la vida de Cristo, con el dolor se revivía la pasión en sus cuerpos. El modelo del Cristo flagelado, se reproducía de manera que se marcaba en la propia carne las heridas, de tal modo que el suplicio era entonces un acto de adoración: se flagelaban para imitar el sacrificio de Cristo azotado por sus verdugos. El cuerpo de las monjas se transformaba en un espacio sagrado, cuando, al lacerarse, se constituían de manera simultánea en altar, víctima y sacerdote, es decir, concentraban en su cuerpo los elementos del sacrificio y de la víctima propiciatoria $^{24}$. Sus relatos, en estados de tribulación son frecuentes:

[...] hacia cuanta penitencia alcanzaban mis fuerzas, y despedazaba mi cuerpo hasta bañar el suelo, y ver correr la sangre. Era casi nada lo que pasaba de sustento, y sólo tenía alivio con los dolores corporales ${ }^{25}$.

El cuerpo barroco, como espacio donde se batían vicios y virtudes, se consolidaba como el lugar donde se encontraba el verdugo y la víctima. Josepha y Jerónima expiaban los pecados de la humanidad, como Cristo, en su propio cuerpo. Su misión era redentora, el convento el espacio redentor. El sacrificio convertía a las monjas en víctimas expiatorias, medio por el cual buscan reconocer su dependencia terrena de lo sagrado. Así, su modelo de santidad, solitario y ascético, encontraba en la penitencia física la posibilidad de sufrir para perfeccionar, elección donde se proyectaban las virtudes cristianas que se debían imitar. Pero también, el cuerpo era el territorio donde actuaba el enemigo, tentándolo, seduciéndolo, influyendo de mil maneras: los sueños, las envidias, los deseos, la enfermedad. El cuerpo perfeccionado y purificado permitía el acercamiento a otra dimensión de la relación con Dios: recibía sensiblemente un repertorio de imágenes que generalmente remitían a sus cuerpos, estas eran las visiones y sueños místicos.

\section{La autoconciencia del cuerpo}

Un elemento fundamental en la experiencia textual barroca es la conciencia del cuerpo. Mediante diversos mecanismos presentes en sus autobiografías, las autoras trasmitían sus percepciones de su corporeidad, de las cuales son notorias las experiencias místicas que se desprenden de las visiones, raptos, suspensiones y delirios, momentos en los que revelaban su propia conciencia de situacionalidad. Asumir la conciencia del cuerpo, se iniciaba a través de la ya mencionada conciencia de sus constantes enfermedades, actitud que las enfrentaba al problema de cómo gobernar un "cuerpo muerto". Este era el espacio donde se confundían las penas del cuerpo con las de espíritu. Cuando Josepha estaba en situaciones de rapto místico,

[...] hacia todas mis diligencias; me clavaba alfileres en la boca y no los sentía, tiraba a arrancarme los cabellos de la cabeza, y me quedaba con la mano pendiente y sumida en aquel letargo $[\ldots]^{26}$.

\footnotetext{
${ }^{24}$ Glantz, "El cuerpo monacal", 201.

${ }^{25}$ Castillo y Guevara, Su vida, 90.

${ }^{26}$ Ibídem, 157.
} 
Esta era la condición que les acercaba al objetivo final del modelo de santidad elegido, modelo donde el cuerpo aspiraba a su completa espiritualización. En este estado Josepha, según sus palabras, duró 14 años, número que en la tradición cristiana y retórica, representaba la doble perfección. Estos arrojos místicos acontecían sólo cuando estaba espiritualmente equilibrada, porque en los momentos de alma tribulada, éstos cesaban ${ }^{27}$.

Llegué a cobrarme a mí misma un horror tan grande, que me era grave tormento el estar conmigo misma. Me faltó del todo el sueño, y cada instante se me hacía una eternidad. Pasaba las noches mirando y clamando a las imágenes de la Virgen Santísima, como el que lucha con las angustias de la muerte, y cuando el gran trabajo de la noche se había pasado, empezaba a temblar y estremecerme de nuevo de los instantes y momentos del día. Tenía un horror a mi cuerpo, que cada dedo de las manos me atormentaba fieramente, la ropa que traía vestida, el aire y luz que $\operatorname{miraba}^{28}$.

Esta conciencia del cuerpo le permitía repetir constantemente en su narración su condición: pobre, sola, despreciada y simple; esclava, vil e ignorante. Cuerpo amorosamente arrojado a su propia miseria, muy de acuerdo al modelo de santidad que habían elegido. Esta era una especie de muerte en vida, muerte del cuerpo, para que el alma pudiera vivir. A los 20 días de nacer, Josepha contaba que tuvo su primera experiencia de muerte, con lo que simbólicamente presentaba una marca que profetizaba su futuro, estableciendo una imagen del cuerpo que representaba el tránsito, siempre llamado para abandonar esta vida.

Pero también, uno de los aspectos más comunes en sus obras, son las visiones, característica de la espiritualidad barroca. En su conjunto, la visiones estaban ensambladas como un elemento típicamente retórico a la manera de un exempla con el cual se quería trasmitir una enseñanza. Las visiones ocurrían por lo general, en momentos de oración intensa, por inspiración divina, una luz que aclaraba algún momento de oscuridad de la fe. Fundamentalmente se trataba de imágenes con características narrativas muy barrocas, pues en el fondo era una puesta en escena, una teatralidad del cuerpo que delimitaban un campo de metáforas y una iconografía imaginaria que también se basaban en los ejercicios de Ignacio de Loyola, especialmente en la composición de lugar, y se reforzaba con la iconografía real.

Había dos tipos de visiones. Por una parte, se encontraban aquellas cuya estructura narrativa se presentaba como alegorías en las que las monjas participaban. En los símbolos alegóricos, Dios se manifestaba para indicarles el camino que debían seguir.

En otra ocasión, estando yo en una ocupación, sentí un impulso interior que me llamaba a la soledad y retiro interior y fue tan vehemente que hube de omitir lo que me divertía. Y fui donde me llamaban, deseando hacer la voluntad de quien así me impelía; y, habiéndome recogido, vi al Señor en un campo, frente a frente conmigo.

\footnotetext{
${ }^{27}$ Ibídem, 159.

${ }^{28}$ Ibídem, 163.
} 
Tenía un arco en la mano y disparando una flecha al corazón, caí. Y el ángel de mi guarda, con gran presteza y lástima, me levantó ${ }^{29}$.

El segundo conjunto de visiones definían espacios en los que se llevaban a cabo encuentros con lo sagrado, y estaban compuestas por imágenes que muchas veces estaban tomadas de la iconografía corriente en su época. El tema tan frecuente de los Desposorios místicos de Catalina de Alejandría, o Santa Rosa de Lima, hacía parte de la composición de lugar en las visiones de Jerónima, el cual se puede comparar con las figuras 2 y 3 :

Había estado muy fatigada de mis continuas enfermedades y con la misma fatiga rezaba como podía el Oficio Divino. Y me pareció que venía a mí una fragancia que me sacaba casi de mis sentidos y luego vi al Niño Jesús que, llegándose a mí y poniéndome las manitas en el hombro me decía: "críame". [...] Y el niño permanecía junto a mí, como que quería abrazarme, o que le alzase. Por último le tomé en brazos y me hacía muchas caricias. Cojíame el rostro y me daba tiernos ósculos ${ }^{30}$.

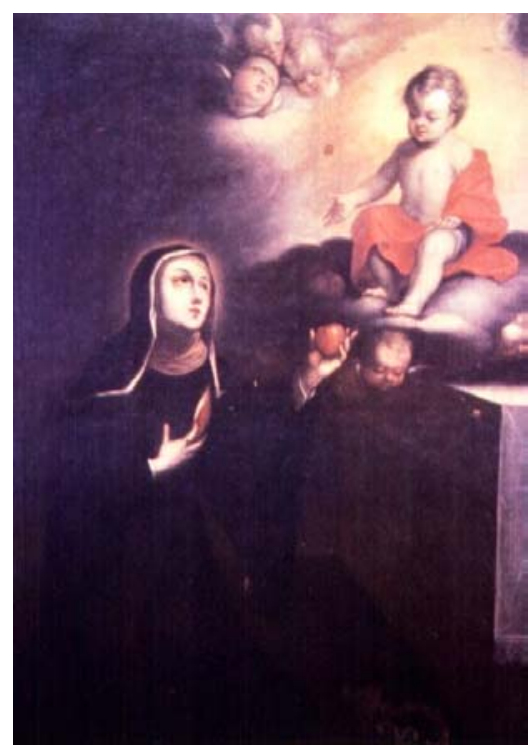

Figura 2. Gregorio Vásquez, Niño Jesús y Santa Gertrudis (548)

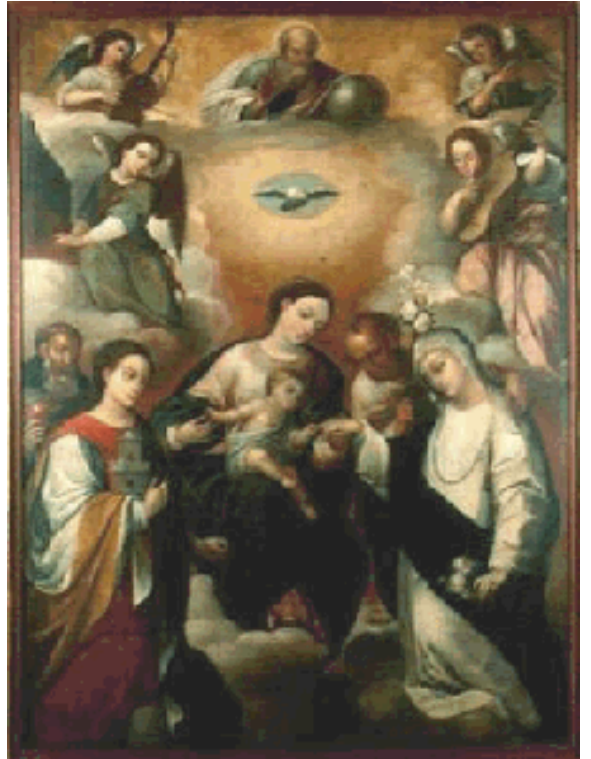

Figura 3. Desposorios místicos de Santa Catalina de Alejandría (006)

Estas visiones funcionaban como una especie de teatro portátil mental, cuyas acciones y personajes provenían de un repertorio preestablecido por la preceptiva retórica que definía y daba forma a estas narraciones. Además, dominadas por la metodología espiritual ignaciana de

\footnotetext{
${ }^{29}$ Robledo, Jerónima Nava y Saavedra, 65.

${ }^{30}$ Ibídem, 97.
} 
la composición de lugar, era elemento retórico que les permitía colocar en un cuerpo, a la manera de teatralización, las angustias, los valores, los dolores. Ignacio aconsejaba poner en marcha la imaginación como apoyo de la meditación y las visiones eran parte de esta práctica que bien conocían las autoras, porque sus directores y confesores, además de sus lecturas, pertenecían a la Compañía.

Particularmente, es interesante observar que las visiones, como el lugar que albergaba la pasión, estaban cargadas de imágenes o sentidos corporales. Las visiones también eran el momento para constatar el abandono del mundo, ya que en el cuerpo se anclaba todo lo que es despreciable. La representación ideal del cuerpo barroco, tal como lo percibía Josepha, tenía esta descripción tomada de una visión de ángeles:

Tenían representación de cuerpos humanos, mas aquella carne era como glorificada, transparente o resplandeciente sin fastidio; mas de un color tan agradable, claro y puro, que por más que diga, antes será oscurecerlo que darlo a entender ${ }^{31}$.

Dios indicaba por medio de estas visiones el trabajo que debía cumplir para acercarse al camino de perfección o al logro de la santidad, cuyo apoyo se encontraba en la humildad y en el sacrificio, modelo de abnegación. La visión se convertía en un emblema que se hacía mediador entre el cuerpo pecador y el cuerpo glorioso que aspira a la santidad.

Junto a las visiones, los sueños se constituían en otro mecanismo mediante el cual Dios le mostraba el camino. Condicionados por las circunstancias, el conjunto de sueños y visiones permitía a las monjas encontrar pistas para su camino de perfección. Se trataba de una especie de premio, recompensa a las tribulaciones y al esfuerzo, en la que Dios se manifestaba refrendándoles su predilección, al tiempo que acrecentaba la fama espiritual de quien las tenía. Este era un recurso importante hacia la espiritualización del cuerpo y la erotización de Dios, el amado esposo.

\section{EI cuerpo de los otros}

En las autobiografías también se empleó el tropo retórico de la humildad, el cual se tematizó en las constantes narraciones de los difíciles acontecimientos que se vivían dentro del convento, asimilados a una especie de experiencia del infierno y al constante asedio del demonio, padre de las disensiones, quien mediatizaba las relaciones con el otro. La presencia del chisme, por ejemplo, subrayaba la abnegación y la humildad. Josepha y Jerónima se fortalecían frente a la mala fama que creaban sus compañeras de clausura, porque al sobrellevar la habladuría se realzaba la humildad, una de sus principales virtudes. Los trabajos eran pesados, la calumnia era constante, el confesor las rechaza, con estas narraciones pretendían resaltar el carácter de la sumisión.

\footnotetext{
${ }^{31}$ Castillo y Guevara, Su vida, 185.
} 
En este contexto, la experiencia de la perdida del mundo como desgarramiento corporal era un elemento esencial en su experiencia mística. En los textos, repudiar al mundo producía un dolor, cuya separación tenía que ver con la ruptura de las apetencias corporales, pero se recuperaba en una especie de placer trascendente. La realidad se alcanzaba en el dolor y el sufrimiento, un cuerpo transfigurado, trasubstancializado a imitación de Jesús crucificado. Experimentaban el dolor del cuerpo negado para lograr la identificación.

Aislarse era separar el cuerpo de la sociedad. Las monjas ocupaban un lugar singular en la sociedad, eran víctimas propiciatorias que concentraban en su cuerpo macerado los pecados del mundo, los asumían y los limpiaban, y a su debido tiempo, insistían por medio de la autobiografía en su vida mortificada. Cuando sus textos se volvían públicos a la vista, adquirían fama de santas, aunque no llegara la canonización eclesiástica. El convento operaba como un mecanismo de sustitución: las religiosas, seres débiles, inocentes practicantes de las virtudes teologales -caritativas y humildes, obedientes, castas y abnegadas- ejercían en su contra un suplicio corporal para ayudar a borrar los pecados del mundo. Cumplían el papel que en el contexto tradicional consumaba la víctima ofrecida en un altar para apaciguar la ira de Dios, o para elevarle peticiones. En este sentido, se convertían en un concepto más complejo y elevado, el cuerpo místico que se encarnaba en el cuerpo social, cuya función era recoger el dolor del mundo. La gran contradicción era ganar el mundo sin perder el alma, y salvar el alma sin perder el cuerpo.

A todas las personas a quien forzosamente había de tratar o ver, les tenía tanto temor, y me llenaban de un pavor y tristeza tan extraordinarios, que me atormentaban las que me querían aliviar; y si viéndolas entrar, me daba un susto que me quedaba como desmayada y temblando: lo mismo era en llamando los padres al torno, o cualquiera persona de fuera ${ }^{32}$.

La autobiografía, de este modo, pretendía representar retóricamente modelos de vidas ejemplares. La elección del arquetipo del Cristo sufriente no reflejaba una experiencia de negación del cuerpo, sino su perfección a partir de la práctica ascética. Se trataba, en últimas, de una experiencia "amorosa" 33 que reflejaba el ascenso de la autoconciencia de sí mismo, experiencia a partir de la cual se creaba aquella comunidad imaginada del cuerpo místico que debía ser el cuerpo social. La retórica del barroco, aquella que construyó la mística del cuerpo en el mundo, le dio lugar a la mística como experiencia sensorial y secular.

\footnotetext{
${ }^{32}$ Ibídem, 163.

${ }^{33}$ La lectura "amorosa" de las autobiografías es la propuesta de Ángela Robledo, editora y prologuista de la autobiografía de Jerónima Nava. Según ella, estas obras se deben leer desde "el amor de la mística como el producto de un sujeto que se enfoca en la enunciación y expresa una estética límite" (Robledo, prólogo de Jerónima Nava y Saavedra, 22).
} 


\section{Bibliografía}

Achury Valenzuela, Darío. "Estudio Preliminar". En, Su vida, escrita por ella misma por mandado de su confesor, por Sor Francisca Josepha de la Concepción. Bogotá: Biblioteca de autores Colombianos, 1956: 39-44.

Arenal, Electa y Stancey Schlau. Untold Sisters. Hispanic Nuns in their Own Works. Albuquerque: University of New Mexico Press, 1989.

Concepción, Sor Francisca Josepha de la. Su vida, escrita por ella misma por mandado de su confesor. Bogotá: Biblioteca de autores Colombianos, 1956.

De Certeau, Michel. La fábula mística, siglos XVI y XVII. México: Universidad Iberoamericana, 1993.

"Historias de cuerpos", Historia y Grafia, no. 9 (1997).

Echeverría, Bolívar. La modernidad de lo barroco. México: Ediciones Era, 1998.

Foucault, Michael. Historia de la sexualidad. México: Fondo de Cultura Económica, 1991.

Gil Tovar, Francisco. "Del aparente barroco en Colombia", Revista del Colegio Mayor de Nuestra Señora del Rosario, no. 52 (1980).

Glantz, Margo. "El cuerpo monacal". En Barrocos y Modernos. Nuevos caminos en la investigación del Barroco Iberoamericano, Petra Schumm ed. Frankfurt: Vervuert Verlag, 1998; Madrid: Iberoamericana, 1998.

Ibsen, Kristine. Women's Spiritual Autobiography In Colonial Spanish America. Gainsville: University Press of Florida, 1999.

Loyola, Ignacio de. Obras. Madrid: Biblioteca de autores Cristianos, 1991.

Nava y Saavedra, Jerónima. Autobiografía de una monja venerable. Edición y estudio preliminar Ángela Inés Robledo. Cali: Centro Editorial Universidad del Valle, 1994.

Rubial, Antonio. La santidad controvertida. México: Fondo de Cultura Económica, 1999.

Weber, Alison. Teresa de Avila and the Rhetoric of Feminity. Princeton: Princeton University Press, 1996. 